\title{
PENEMPATAN KOMISI PEMBERANTASAN KORUPSI SEBAGAI ORGAN UNDANG-UNDANG DASAR NEGARA RI TAHUN 1945
}

\author{
Josef M. Monteiro ${ }^{1}$
}

\begin{abstract}
Komisi Pemberantasan Korupsi as an auxiliary organ is independent and forms as a trigger mechanism of public scepticism against weaknesses of existing law enforcement institution apparatus i.e the state Police and Attorney General. The $K P K$, therefore, has legal structure and infrastructure with extraordinary power or competency such as inquiring, close - investigation, sap - tapping and prosecution. In fact, the KPK born by law faces various abstecles in its efforts to wipe out corruption against state institution born by the 1945 Constitution. Consequently, it is not easy to a lower institution to control higher institution as a whole. Besides, the exsistence of KPK as a product of law facing problematic situation that is the law of KPK in formality (wet informele zin) made and determined by legislative body and presidency, therefore the law of KPK can easily be cancelled by the two institutions. In addition, the law of KPK materially (wet materiele zin), the content or substance of KPK act can easily be revise by the government and the DPR to infiltrate their political interest so that the new $K P K$ law or orthodox reflecting more political vision. The product of such legal act tends to be conservative law or orthodox reflecting more elitist political interest in the centre of executive and legislative power. To avoid paralyzing the $K P K$ existence the placement of KPK organ in the main body of 1945 Constitution is urgently needed.
\end{abstract}

Keywords: corruption, the organ of state, authority, revision

\begin{abstract}
Abstrak
Komisi Pemberantasan Korupsi sebagai sebuah organ tambahan bersifat independen dan berperan sebagai mekanisme pemicu ketidakpercayaan khayalak terhadap lemahnya aparat penegak hukum yakni Kepolisian dan Kejaksaan. KPK, karena itu, memiliki infrastruktur dan struktur hukum dengan kekuasaan yang luar biasa atau kompetensi untuk melakukan penyidikan, penyelidikan, penyadapan dan penuntutan. Pada kenyataannya, KPK yang lahir berdasarkan hukum menghadapi banyak rintangan dalam usahanya memberantas korupsi dalam organ-organ negara sebagaimana diatur dalam UUD 1945. Akibatnya, institusi yang lebih rendah menghadapi kesulitan dalam mengontrol institusiinstitusi yang lebih tinggi. Di samping itu, keberadaan KPK sebagai sebuah produk hukum menghadapi situasi yang problematik, karena Undang-undang yang mengatur KPK secara formal (wet in formeele gezin) dibuat dan ditentukan oleh badan legislatif dan badan kepresidenan, sehingga Undang-Undang KPK
\end{abstract}

\footnotetext{
${ }^{1}$ Dosen Tetap Fakultas Hukum Universitas Nusa Cendana Kupang NTT. Alamat kontak: monteirojosef@yahoo.com.
} 
dapat dengan mudah dibatalkan oleh kedua institusi tersebut. Terlebih lagi, Undang-Undang KPK secara material (wet in materieele gezin) yakni kandungan atau isi dari Undang-Undang tersebut, dapat dengan mudah diubah oleh Pemerintah dan DPR untuk menyusupkan kepentingan politiknya, sehingga Undang-Undang KPK yang baru lebih mencerminkan visi politik yang bersangkutan. Produk dari undang-undang yang demikian cenderung menjadi konservatif atau ortodoks, mencerminkan kepentingan politik elit di pusat kekuasaan eksekutif dan legislatif. Untuk menghindari dilumpuhkannya keberadaan KPK, maka pengaturannya dalam batang tubuh UUD 1945 mendesak untuk dilakukan.

Kata Kunci: korupsi, organ negara, kewenangan, revisi

\section{Latar Belakang}

Perubahan Undang-Undang Dasar Negara RI Tahun 1945 telah berimplikasi terhadap struktur organisasi negara, termasuk bentuk serta fungsi lembagalembaga negara. Selain itu berdirinya lembaga-lembaga negara baru berupa Dewan (council), Komisi (commission), Komite (committee), Badan (board), atau Otorita (authority). Lembaga-lembaga tersebut dikenal sebagai Auxiliary Organ atau Auxiliary Institutions yang diartikan sebagai lembaga negara yang bersifat sebagai penunjang. Adapun salah satu lembaga negara bantu yang bersifat penunjang adalah Komisi Pemberantasan Korupsi (KPK) yang dibentuk berdasarkan amanat Undang-Undang Nomor 30 Tahun 2002 Tentang Komisi Pemberantasan Tindak Pidana Korupsi. Lembaga ini dibentuk sebagai salah satu bagian dari agenda terpenting dalam pembenahan tata pemerintahan di Indonesia. Kehadiran KPK dilatarbelakangi karena rendahnya kepercayaan masyarakat terhadap lembaga penegakan hukum yakni Kejaksaan dan Kepolisian dalam memberantas korupsi.

Dalam upaya untuk memberantas tindak pidana korupsi di Indonesia, KPK memiliki beberapa kewenangan, antara lain berkoordinasi dengan institusi negara lainnya untuk memberantas korupsi, melakukan penyelidikan, penyidikan, dan penututan terhadap tindak pidana korupsi, melakukan pendaftaran dan pemeriksaan terhadap laporan harta kekayaan penyelenggara negara, melaksanakan pendidikan anti korupsi pada setiap jenjang pendidikan, dan sebagainya. Peranan KPK dalam pemberantasan korupsi yang signifikan ini telah ditunjukannya dengan pengungkapan kasus-kasus korupsi di sektor-sektor krusial di ranah kebijakan publik, diantaranya adalah sektor APBN dan APBD, sektor pelayanan dasar seperti pendidikan dan kesehatan, sektor perpajakan dan birokrasi serta sektor politik.

Namun KPK dalam menjalankan tugas dan wewenangnya untuk memberantas korupsi ternyata tidaklah mudah. Dalam praktiknya, KPK tidak mampu menjangkau semua lembaga negara karena alasan normatif. Dalam hal ini keberadaan KPK yang secara kelembagaan lahir dari undang-undang, akan kesulitan melakukan akses pemberantasan korupsi terhadap lembaga-lembaga 
negara yang legitimasinya merupakan ketentuan langsung dari amanat UndangUndang Dasar Negara RI Tahun 1945.

Berdasarkan hierarki peraturan perundang-undangan di Indonesia sebagaimana diatur dalam Undang-Undang Nomor 10 Tahun 2004 Tentang Pembentukan Peraturan Perundang-Undangan, jo. Undang-Undang Nomor 12 Tahun 2011 Tentang Pembentukan Peraturan Perundang-Undangan disebutkan tata urutan peraturan perundang-undangan yaitu: (1) Undang-Undang Dasar Negara RI Tahun 1945, (2) Ketetapan Majelis Permusyawaratan Rakyat, ((3) Undang-Undang/Peraturan Pemerintah Pengganti Undang-Undang, (4) Peraturan Pemerintah, (5) Peraturan Presiden, (6) Peraturan Daerah Provinsi, dan (7) Peraturan Daerah Kabupaten/Kota. Apabila mengacu pada asas lex superior derogat legi inferiori, ${ }^{2}$ maka KPK yang lahir dari undang-undang mengalami berbagai kendala dalam rangka memberantas korupsi terhadap lembaga negara yang lahir dari Undang-Undang Dasar Negara RI Tahun 1945. Dalam hal ini tidaklah mudah bagi lembaga inferior mampu secara keseluruhan mengawasi lembaga superior. Problematikanya tidaklah lebih menyangkut dalil kesetaraan kelembagaan sehingga KPK tidak akan mungkin secara maksimal dapat menuntaskan kasus-kasus korupsi di Indonesia jika hanya diatur dengan undangundang.

Sempitnya ruang gerak KPK dalam memberantas korupsi yang terjadi pada lembaga-lembaga negara yang diatur dengan Undang-Undang Dasar Negara RI Tahun 1945, semakin diperparah lagi jika KPK dalam proses pemberantasan korupsi dinilai bersifat diskriminatif. Dapatlah dipahami bahwa pemberantasan korupsi dalam realitasnya sangat berkaitan dengan politik kekuasaan dan politik uang sehingga jika KPK tidak menuntaskan pengaduan masyarakat mengenai korupsi maka tentunya KPK akan bertindak tebang pilih kasus. Tercatat pada kuartal pertama 2011 saja, KPK menerima 1898 pengaduan masyarakat terkait dengan tindak pidana korupsi. ${ }^{3}$ Berdasarkan jumlah pengaduan tersebut kini masyarakat menunggu bagaimana tindak lanjut penangan KPK sehingga benarbenar memenuhi rasa keadilan masyarakat.

Berdasarkan keadaan tersebut diatas maka tulisan ini dimaksudkan untuk mengkaji penguatan eksistensi KPK agar secara hierarki KPK ditempatkan setara dengan lembaga negara lainnya yang diatur dalam Undang-Undang Dasar Negara RI Tahun 1945. Diharapkan agar nantinya terjadi reposisi KPK yang tidak lagi hanya sebagai suatu lembaga negara inferior yang sub ordinat terhadap DPR, Presiden, DPD, Mahkamah Konstitusi, Komisi Yudisial, BPK, Bank Sentral, dan Komisi Pemilihan Umum (KPU), melainkan KPK menjadi lembaga negara yang bebas dari hambatan konstitusional untuk menjalankan fungsinya memberantas korupsi.

\footnotetext{
${ }^{2}$ Lex superior derogat legi inferiori, jika dimaknai secara harafia artinya hukum yang derajatnya lebih tinggi membatalkan hukum yang derajatnya lebih rendah.

${ }^{3}<$ http://www.kpk.go.id>, diakses tanggal 2 Mei 2011.
} 


\section{Konsep Organ Negara}

Konsepsi tentang lembaga negara yang dalam bahasa Belanda disebut staatsorgaan, jika diartikan ke dalam bahasa Indonesia ialah alat perlengkapan negara, badan negara atau dapat disebut juga organ negara. Istilah alat kelengkapan negara, badan negara, lembaga negara ataupun organ negara sering digunakan dalam konteks yang sama dan merujuk pada pengertian yang sama, yaitu yang membedakannya dengan lembaga swasta atau masyarakat. Lembaga negara terkadang disebut juga dengan istilah lembaga pemerintahan, lembaga pemerintahan non departemen, atau lembaga negara saja. ${ }^{4}$

Berkaitan dengan lembaga yang dibentuk bukan oleh masyarakat atau disebut sebagai lembaga negara atau organ negara ini apabila dihubungkan dengan fungsi pemerintahan, maka lembaga negara atau organ negara berada dalam ranah legislatif, eksekutif, dan yudisiil. Oleh karena itu Hans Kelsen dalam bukunya yang berjudul the General Theory of Law and State membagi lembaga negara atau organ negara ke dalam dua bagian (luas dan sempit), meliputi:

1. Whoever fulfills a function determined by the legal order is an organ. ${ }^{5}$ Menurut Hans Kelsen setiap individu, orang, ataupun lembaga dapat disebut sebagai suatu organ negara bila berfungsi untuk menciptakan norma (norm creating) dan menjalankan norma (norm applying) sekaligus. Dalam hal ini Dewan Perwakilan Rakyat (DPR) berdasar pada Pasal 20 Ayat (1) UndangUndang Dasar Negara RI Tahun 1945 yang mememgang kekuasaan membentuk undang-undang, adalah organ negara yang norm creating sekaligus norm applying. Begitu pula Majelis Permusyawaratan Rakyat (MPR), termasuk kategori lembaga negara atau organ negara dalam pengertian ini yang dilegitimasikan oleh Pasal 3 Ayat (1) Undang-Undang Dasar Negara RI Tahun 1945. Warga negara, menurut Hans Kelsen juga organ negara dalam pengertian yang luas. Sebagai contoh dalam pemilihan umum di Indonesia, berdasar Pasal 6A Ayat (1) Undang-Undang Dasar Negara RI Tahun 1945, Presiden dan Wakil Presiden dipilih dalam satu pasangan secara langsung oleh rakyat, maka rakyat termasuk organ negara karena mempunyai fungsi menjalankan norma (norm applying) yaitu menjalankan Undang-Undang Dasar Negara RI Tahun 1945.

2. ...he personally has a specific legal position. ${ }^{6}$ Pengertian pertama tersebut disempurnakan lagi bahwa organ negara, dalam hal ini yakni tiap individu dapat dikatakan sebagai organ negara bila secara pribadi ia memiliki kedudukan hukum tertentu. Ciri-ciri organ negara dalam pengertian kedua

\footnotetext{
${ }^{4}$ Jimly Asshiddiqie, seperti yang dikutip oleh Jazim Hamidi, dkk, "Teori dan Politik Hukum Tata Negara", (Yogyakarta: Total Media, 2009), hal. 55.

${ }^{5}$ Jimly Asshiddiqie, "Perkembangan dan Konsolidasi Lembaga Negara Pasca Reformasi", (Jakarta: Sekretariat Jenderal dan Kepaniteraan Mahkamah Konstitusi RI, 2006), hal. 31.

${ }^{6}$ Ibid., hal. 37.
} 
ini meliputi: (1) Organ negara itu dipilih atau diangkat untuk menduduki jabatan atau fungsi tertentu; (2) Fungsi itu dijalankan sebagai profesi utama bahkan secara hukum bersifat eksklusif; (3) Karena fungsinya itu, ia berhak untuk mendapatkan imbalan gaji dari negara.

Organ negara dalam pengertian sempit menurut Hans Kelsen yakni meniadakan warga negara atau rakyat. Faktor utamanya adalah tidak ada kaitannya dengan jabatan untuk menjalankan fungsi tertentu. Karena rakyat tidak termasuk pejabat atau yang memegang jabatan dalam organisasi kenegaraan, maka rakyat tidak termasuk organ negara dalam pengertian yang kedua tersebut.

Hal yang sama dikemukakan pula oleh Jimly Asshiddiqie yang memandang konsep organ negara atau lembaga negarta tidak bisa dibatasi pada pandangan Trias Politica Montesqieu yaitu legislatif, eksekutif, ataupun yudisiil saja. Karena pada umumnya, dewasa ini ketiga cabang kekuasaan tersebut telah saling bersentuhan dan saling mengendalikan satu dengan yang lainnya sesuai dengan prinsip cheks and balances. Jimly mengkategorikan dalam lima lapisan atau bagian meliputi: ${ }^{7}$

1. Dalam arti yang paling luas, lembaga negara mencakup setiap individu yang menjalankan fungsi menciptakan hukum (law creating) dan fungsi menerapkan hukum (law applying). Titik berat dari pengertian yang luas ini adalah kata-kata setiap individu. Adapun individu tersebut dapat siapa saja (baik rakyat ataupun ketiga cabang kekuasaan) dalam konteks law creating dan law applying, contohnya pemilihan umum yang dilaksanakan oleh seluruh rakyat banyak.

2. Pengertian kedua, yang cenderung luas namun lebih sempit dari pada pengertian pertama, menyebutkan bahwa lembaga negara mencakup fungsi tersebut diatas dan juga mempunyai posisi sebagai atau berada dalam struktur jabatan kenegaraan atau jabatan pemerintahan. Kunci dari pengertian lembaga negara pada pengertian kedua ini terletak pada kata-kata individu yang menjabat posisi tertentu di pemerintahan atau kenegaraan. Jadi warga negara atau rakyat sudah tidak termasuk dalam lembag negara.

3. Pengertian ketiga mengartikan lembaga negara dalam arti sempit sebagai badan atau organisasi yang menjalankan fungsi menciptakan hukum dalam kerangka struktur dan sistem kenegaraan atau pemerintahan. Dalam pengertian yang terakhir ini, lembaga negara mencakup badan-badan yang dibentuk berdasarkan konstitusi ataupun peraturan berlaku perundangundangan lain dibawahnya yang berlaku di suatu negara. Dalam pengertian ketiga ini organ negara yang lebih sempit dari pengertian kedua dan diartikan sebagai badan atau organisasinya (bukan orang atau individunya), dalam konteks struktur kenegaraan. Dan tak kalah pentingnya bahwa le,mbaga negara itu meliputi lembaga negara yang dibentuk berdasarkan

\footnotetext{
${ }^{7}$ Ibid., hal. 40-41.
} 
UUD, UU. Peraturan Presiden, ataupun oleh keputusan yang tingkatannya lebih rendah, baik di tingkat pusat ataupun daerah.

4. Pengertian organ negara yang keempat yang lebih sempit lagi, yaitu lembaga negara hanya terbatas pada pengertian lembaga-lembaga negara yang dibentuk berdasarkan tingkatnya lebih rendah, baik di tingkat pusat ataupun di tingkat daerah. Pengertian UUD, UU, atau peraturan yang lebih rendah. Yang menjadi kunci pokok untuk membedakan pengertian lembaga negara yang keempat ini adalah pada kata-kata "keputusan-keputusan yang tingkatannya lebih rendah, baik di tingkat pusat ataupun di daerah." Pengertian organ yang ketiga mencakup lembaga negara mulai dari tingkat pusat sampai di daerah, termasuk pula kecamatan, kelurahan, dan lain-lain (RT/Rukun Tetangga, RW/Rukun Warga). Sedangkan pengertian organ negara yang keempat hanya terbatas pada lembaga negara di tingkat pusat dan lembaga negara di tingkat daerah saja (hanya sampai Dewan Perwakilan Rakyat Daerah/DPRD saja).

Berdasarkan pengertian tersebut diatas, dapatlah dikatakan bahwa Jimly Asshiddiqie, membagi lembaga negara atau organ negara di Indonesia sebagai berikut; organ negara atau lembaga negara yang diatur dan dibentuk oleh UndangUndang Dasar sehingga merupakan organ konstitusi (Constitutional Organ), kemudian organ negara atau lembaga negara yang dibentuk berdasarkan UndangUndang sehingga merupakan organ Undang-Undang, sementara yang lain lagi organ negara atau lembaga negara yang dibentuk karena Keputusan Presiden, dan terakhir yakni yang lebih rendah tingkatannya adalah organ negara atau lembaga negara yang dibentuk dan diberi kekuasaan berdasarkan Peraturan Daerah. ${ }^{8}$

Dengan demikian pada dasarnya menurut Jimly Asshiddiqie dalam UUD 1945 pasca amandemen terdapat kurang lebih 34 lembaga atau organ negara yang disebut baik secara eksplisit maupun emplisit. Ke-34 organ negara tersebut dapat dibedakan dari dua segi yaitu dari segi fungsi dan dari segi hierarki. Dari segi fungsinya, ke-34 organ negara tersebut, ada yang bersifat utama atau primer, dan ada pula yang bersifat sekunder atau penunjang (auxiliary). Sedangkan dari segi hierarkinya, ke-34 organ negara dapat dibedakan ke dalam tiga lapis, yaitu lembaga tinggi negara, lembaga negara, dan lembaga daerah. ${ }^{9}$

\section{Problematika Kedudukan KPK diatur dengan Undang-Undang}

Kejahatan korupsi merupakan masalah serius yang dihadapi oleh hampir semua negara di dunia sehingga dalam resolusi "Corruption in government" PBB mengenai "the Prevention of Crime and the Treatment of Offenders di Havana (Cuba) tahun 1990, antara lain disebutkan korupsi di kalangan pejabat publik adalah dapat menghancurkan efektivitas potensial dari semua

8 Jimly Asshiddiqie, "Hubungan Antar Lembaga Negara Pasca Perubahan UUD 1945", (Jakarta: Gramedia, 2008), hal. 31.

${ }^{9}$ Jimly Asshiddiqie, Perkembangan... Op. Cit., hal. 195. 
jenis program pemerintah; dapat mengganggu atau menghambat pembangunan; dan menimbulkan korban individual maupun kelompok masyarakat.

Di dalam Kongres PBB ke-9 tahun 1995 di Kairo, Mesir, antara lain juga ditegaskan, bahwa korupsi merupakan masalah yang dapat membahayakan stabilitas dan keamanan masyarakat; merusak nilai-nilai demokrasi dan moralitas; dan membahayakan pembangunan sosial, ekonomi, dan politik. Selain itu di dalam UN Convention Against Corruption 2003 antara lain dinyatakan bahwa korupsi merupakann ancaman bagi keamanan dan kestablian masyarakat; merusak nilai-nilai dan lembaga-lembaga demokrasi; menbahayakan "pembangunan berkelanjutan" dan "rule of law", dan mengancam stabilitas politik. ${ }^{10}$

Berkaitan dengan hal tersebut praktek korupsi di Indonesia masih merupakan suatu perbuatan yang mengarah pada beyond the law. Hal ini disebabkan banyak faktor yang menentukan, antara lain kekuasaan, dan kuatnya para economic power dimana pengaruh kekuasaan ekonomi (konglomerat) dan beraucratic power sebagai kekuasaan umum (pejabat birokrasi) telah memposisikan status beyond the law. ${ }^{11}$ Keadaan ini semakin diperparah dengan adanya perlawanan balik terutama oleh para koruptor dan mereka yang terindikasi korupsi, untuk memperlemah upaya pemberantasan korupsi. ${ }^{12}$ Oleh karena itu dalam rangka menghadapi korupsi maka ditetapkanlah sejumlah aturan tindak pidana korupsi seperti Kitab Undang-Undang Hukum Pidana (KUHP), Undang-Undang Nomor 3 Tahun 1971 Tentang Pemberantasan Korupsi yang kemudian undang-undang ini diubah dengan Undang-Undang Nomor 31 Tahun 1999 dan diubah lagi dengan Undang-Undang Nomor 20 Tahun 2001. Sebagaimana dimanatkan dalam Undang-Undang Nomor 20 Tahun 2001 harus dibentuk sebuah Komisi Pemberantasan Tindak Pidana Korupsi, maka DPR bersama-sama Presiden menetapkan Undang-Undang Nomor 30 Tahun 2002 Tentang Komisi Pemberantasan Korupsi (KPK). ${ }^{13}$

Lahirnya Komisi Pemberantasan Korupsi (KPK) sebagai sebuah lembaga negara bantu yang independen merupakan trigger mechanism atas skeptisme publik terhadap lemahnya institusi penegak hukum yang ada yakni POLRI dan Kejaksaan Agung. Oleh karena itu KPK memiliki sarana

${ }^{10}$ Barda Nawawi Arief, Beberapa Masalah dan Upaya Peningkatan Kualitas Penegakan Hukum Pidana Dalam Pemberantasan Korupsi, dalam Jurnal Keadilan, Vol.5 No.1 Tahun 2011, hal. 33 .

11 Indriyanto Seno Adji dalam Satya Arinanto, "Memahami Hukum", (Jakarta: Raja Grafindo Persada, 2009), hal. 164.

${ }^{12}$ Lihat Moh,Mahfud MD, Sudah Habis Teori di Gudang, dalam Harian Kompas, 2005.

13 Aji Sekarmaji, Pemberantasan Kejahatan Korupsi Dalam Rangka Proses Penyesuaian Dengan Konvensi PBB Anti Korupsi, dalam Jurnal Hukum dan Pembangunan, Tahun ke-39 No.2, April 2009, hal. 275 
dan prasarana hukum dengan tingkat kewenangan yang luar biasa atau extra ordinary power antara lain penyelidikan, penyidikan, penyadapan, dan penuntutan. Menurut Pasal 11 Undang-Undang Nomor 30 Tahun 2002 disebutkan bahwa KPK memiliki kewenangan dalam hal-hal berikut:

a). Tindak pidananya melibatkan pejabat yang tugas dan kewajibannya terkait erat dengan penegakan hukum atau apabila tindak pidananya melibatkan pejabat-pejabat tinggi pemerintah

b). Tindak pidana tersebut menarik perhatian publik dan menimbulkan keresahan di dalam masyarakat

c). Tindak pidana tersebut mengakibatkan kerugian negara dengan jumlah minimum Rp. 1.000.000.000,- (satu milyar rupiah).

Namun demikian KPK dalam melaksanakan kewenangannya untuk memberantas korupsi tidaklah berarti tanpa ada problem, justru problematika yang dihadapi adalah bersifat yuridis yakni; Pertama, adanya upaya beberapa kalangan tertentu yang mengajukan permohonan judicial review atas Undang-Undang Nomor 20 Tahun 2002 Tentang Komisi Pemberantasan Tindak Pidana Korupsi ke Mahkamah Konstitusi. Adapun yang dimaksud dengan judicial review adalah menguji suatu peraturan perundang-undangan terhadap peraturan perundang-undangan diatasnya dengan ukuran asas peraturan perundang-undangan, sejauhmana peraturan perundang-undangan dibawahnya bersesuai atau bertentangan (tegengesteld) dengan peraturan perundang-undangan diatasnya. ${ }^{14}$ Pengajuan judicial review ke Mahkamah Konstitusi untuk menguji undangundang KPK tersebut berdasarkan ketentuan Pasal 24C Ayat (1) UndangUndang Dasar Negara RI Tahun 1945 yang menyebutkan bahwa lembaga negara yang berwenang untuk menguji konstitusionalitas tidaknya suatu undang-undang adalah Mahkamah Konstitusi. Kewenangan Mahkamah Konstitusi ini juga telah dikonkretisasi dalam Undang-Undang Nomor 4 Tahun 2004 Tentang Kekuasaan Kehakiman yang menegaskan antara lain Mahkamah Konstitusi berwenang mengadili pada tingkat pertama dan terakhir, yang putusannya bersifat final dalam hal menguji undang-undang terhadap Undang-Undang Dasar Negara RI Tahun 1945.

Berkaitan dengan hal tersebut maka para pemohon judicial review mempersoalkan antara lain eksistensi KPK, dengan menghadapkan Pasal 2, Pasal 3, dan Pasal 20 UU-KPK dengan Pasal 1 Ayat (3) Undang-Undang Dasar Negara RI Tahun 1945 yakni prinsip negara hukum. Dikatakan oleh para pemohon bahwa ketiga pasal UU-KPK tersebut bertentangan dengan konsep negara di dalam Undang-Undang Dasar Negara RI Tahun 1945 yang telah menetapkan delapan organ negara yang mempunyai kedudukan yang

\footnotetext{
${ }^{14}$ I Gde Pantja Astawa, "Dinamika Hukum dan Ilmu Perundang-Undangan di Indonesia", (Bandung: Alumni, 2008), hal. 121.
} 
sama atau sederajat yang secara langsung mendapat fungsi konstitusional dari UUD yaitu MPR, Presiden, DPR, DPD,BPK, MA, MK, dan KY.

Menurut Moh.Mahfud MD, Undang-Undang Dasar Negara RI Tahun 1945 menetapkan 8 (delapan) organ negara yang sederajat, akan tetapi hal ini bukan berarti bahwa pembuat undang-undang tidak dapat membuat undang-undang khusus untuk membentuk lembaga negara baru (KPK, dan sebagainya) guna melaksanakan tugas pencapaian tujuan negara. Telah ada ratusan undang-undang yang secara tak langsung dibuat karena fungsi atau perintah langsung dari Undang-Undang Dasar Negara RI Tahun $1945 .^{15}$

Selain itu para pemohon juga mempersoalkan bahwa pemberian kewenangan kepada KPK untuk melakukan penyelidikan, penyidikan, dan penuntutan adalah tidak sah karena menimbulkan ketidakpastian hukum sebagaimana dituntut oleh Pasal 28D Ayat (1) Undang-Undang Dasar Negara RI Tahun 1945. Kepastian hukum menuntut ketegasan berlakunya suatu aturan hukum (lex cetra) yang mengikat secara tegas dan tidak meragukan dalam pemberlakuannya. Dikatakan bahwa pemberlakuan Pasal 6 huruf c UU-KPK menyebabkan muculnya pertentangan antara dua UU atau lebih yang berlaku mengikat pada saat yang sama.

Kemudian dari pada itu, para pemohon mempersoalkan juga ketentuan Pasal 12 Ayat (1) huruf a UU-KPK yang memberi kewenangan kepada KPK untuk menyadap dan merekam pembicaraan dalam menangani kasus dugaan korupsi. Menurut para pemohon, hal itu bertentangan dengan Pasal 28D Ayat (1), Pasal 28F, dan Pasal 28G Ayat (1)

Undang-Undang Dasar Negara RI Tahun 1945 karena jelas-jelas melanggar hak warga negara dari rasa aman untuk berkomunikasi dan melanggar asas praduga tak bersalah. ${ }^{16}$

Kedua, problematika yuridis lainnya adalah sulitnya KPK melakukan akses pemberantasan korupsi terhadap lembaga negara yang legitimasinya merupakan ketentuan langsung amanat Undang-Undang Dasar Negara RI Tahun 1945. Hal ini disebabkan keberadaan KPK secara kelembagaan lahir dari Undang-Undang dan bukannya Undang-Undang Dasar Negara RI Tahun 1945.

Dalam hierarki Peraturan Perundang-Undangan disebutkan bahwa Undang-Undang sebagai peraturan perundang-undangan kedudukannya dibawah Undang-Undang Dasar Negara RI Tahun 1945. Ketentuan demikian dapat dipahami dalam Undang-Undang Nomor 10 Tahun 2004 Tentang Pembentukan Peraturan Perundang-Undang jo Undang-Undang Nomor 12 Tahun 2011 Tentang Pembentukan Peraturan PerundangUndangan sebagai berikut:

15 Moh.Mahfud MD, "Perdebatan HTN Pasca Amandemen Konstitusi", (Jakarta: Raja Grafindo, 2010), hal. 197.

${ }^{16}$ Uraian mengenai hal ini disunting oleh Moh.Mahfud MD, Expert Meeting tentang Permohonan Judicial Review UU-KPK, makalah expert meeting di Pusat Kajian Anti Korupsi (PUKAT) UGM, ICM Yogyakarta, dan Kemitraan Jakarta, tanggal 12-13 Oktober 2006. 
(a) Undang-Undang Dasar Negara RI Tahun 1945;

(b) Ketetapan Majelis Permusyawaratan Rakyat;

(c) Undang-Undang/Peraturan Pemerintah Pengganti Undang-Undang;

(d) Peraturan Pemerintah;

(e) Peraturan Presiden;

(f) Peraturan Daerah Provinsi;

(g) Peraturan Daerah Kabupaten/Kota.

Berdasarkan ketentuan tersebut dan dengan mengacu pada asas lex superior derogat legi inferior, dapatlah dimengerti bahwa kewenangan KPK yang lahir dari undang-undang akan mengalami kendala dalam memberantas korupsi terhadap lembaga negara yang kewenangannya secara atribusi $^{17}$ dari Undang-Undang Dasar Negara RI Tahun 1945. Bahkan kedudukan KPK yang hanya diatur dengan undang-undang ini dapat mengakibatkan KPK sewaktu-waktu dapat dibubarkan oleh Pemerintah dan DPR.

Dengan perkataaan lain bahwa meskipun KPK memiliki kewenangan superbody yang terlepas dari intervensi legislatif, eksekutif, dan judisiil, akan tetapi DPR dan Presiden dapat sewaktu-waktu membubarkan KPK. Hal ini dapatlah dipahami karena berdasarkan ketentuan Pasal 20 UndangUndang Dasar Negara RI Tahun 1945 disebutkan bahwa DPR dan Presiden membentuk undang-undang. Oleh karena itu Undang-Undang KPK secara formal (wet in formele zin) dibuat dan ditetapkan oleh DPR dan Presiden, maka undang-undang KPK mudah dicabut oleh kedua lembaga negara yang membentuknya. Jika terjadi pencabutan undang-undang KPK oleh DPR dan Presiden maka dapat mengakibatkan KPK dibubarkan, dan berdampak pada hilangnya kepercayaan publik kepada DPR dan Presiden karena dinilai mementahkan agenda pemberantasan korupsi. Keadaaan ini tentunya semakin menumbuh kembangkan peningkatan angka korupsi yang berdampak lanjutan pada keterpurukan dan pemiskinan masyarakat.

Selain itu secara materil (wet in materiele zin), isi atau substansi dari undang-undang KPK mudah direvisi oleh pemerintah dan DPR guna menyusupkan kepentingan politiknya masing-masing. Hal ini dapat terlihat dari rencana Komisi Hukum (III) DPR yang cukup serius mempersiapkan revisi Undang-Undang Nomor 30 Tahun 2002 tentang Komisi Pemberantasan Korupsi (UU KPK), yang ditargetkan pembahasan perubahan UU KPK akan dilaksaanakan mulai Januari 2012. Oleh karena itu jika revisi atas undang-undang tersebut dimaksudkan untuk penguatan KPK dapatlah dipahami, akan tetapi sebaliknya jikalau revisi undangundang tersebut justru untuk melemahkan KPK maka tentunya akan mematikan upaya pemberantasan korupsi.

\footnotetext{
${ }^{17}$ Maarseven menjelaskan kewenangan diperoleh melalui 3 (tiga) sumber yakni; (a) atribusi adalah wewenang yang melekat pada suatu jabatan, yang bersumber langsung dari peraturan perundang-undangan, (b) delegasi adalah pelimpahan wewenang, dan (c) mandat adalah pelimpahan wewenang kepada bawahan dan dimaksudkan untuk membuat keputusan atas nama pejabat tata usaha negara yang memberi mandat.
} 
Adapun rencana revisi substansi undang-undang KPK, terbagi atas beberapa isu di antaranya adalah; ${ }^{18}$ isu pertama menyangkut proses rekrutmen penyidik dan jaksa penuntut umum atau JPU. Dalam hal ini yang akan diperdebatkan adalah mengenai penyidik dan jaksa dari sipil atau tetap diambil dari kepolisian dan kejaksaan.

Isu kedua mengenai lima tugas KPK, yakni penindakan, pencegahan, koordinasi, supervisi, dan pengawasan. Isu ketiga, masalah penyadapan juga menjadi bahasan penting dalam revisi UU KPK. Hal yang akan diperdebatkan yakni apakah penyadapan itu dilakukan pada tahap penyelidikan atau penyidikan. Saat ini KPK dapat melakukan penyadapan ketika masih proses penyelidikan. Isu keempat menyangkut laporan harta kekayaan pejabat negara (LHKPN). Dalam UU KPK saat ini, tidak diatur sanksi untuk pejabat negara yang tidak melaporkan harta kekayaannya. Isu kelima, berkaitan dengan kewenangan penyitaan dan penggeledahan oleh KPK yang dianggap terlalu luas juga akan diperdebatkan. DPR akan menimbang, apakah perlu izin dari pengadilan atau tidak untuk menyita dan menggeledah.

Isu keenam yang cukup ramai menjadi perbincangan publik, yakni pelarangan penerbitan surat penghentian penyidikan atau SP3, akan dikaji untuk tetap dipertahankan atau tidak. Pada dasarnya wewenang tidak mengeluarkan SP3 seharusnya tetap dipertahankan untuk mencegah "perdagangan kasus". Isu ketujuh terkait prinsip kolektif kolegial pimpinan KPK. Prinsip ini berlaku sejak pelantikan pimpinan hingga akhir masa jabatan atau tidak, itu yang akan diperdebatkan. Isu kedelapan, yakni politik pemberantasan korupsi ke depan. Dalam hal ini yang akan diperdebatkan, apakah KPK mengutamakan penindakan atau pencegahan. Kalau fokus pada penindakan, maka apakah harus membentuk lembaga baru untuk melakukan pencegahan, atau fokusnya pada pencegahan, berarti penindakan diserahkan ke kepolisian atau kejaksaan.

Isu kesembilan terkait masalah penanganan kasus korupsi, khususnya mengenai nilai minimum kerugian negara yang dapat ditangani KPK, yakni Rp 1 miliar. Ada yang menilai KPK seharusnya menangani kasus dengan nilai kerugian besar, seperti di atas Rp 10 miliar. Isu kesepuluh, KPK harus fokus, apakah mau menyelamatkan uang negara atau menghukum orang. Hal ini disebabkan selama ini KPK fokus lebih kepada menghukum orang, lebih pada kriminalisasinya daripada menyelamatkan uang negara.

Berdasarkan substansi rancangan revisi kewenangan KPK tersebut dapat menimbulkan perbedaan penafsiran yang dapat memunculkan penilaian bahwa undang-undang KPK nantinya lebih merupakan pencerminan visi elit politik. Produk hukum seperti ini dapat mengarah kepada produk hukum konservatif atau ortodoks yakni produk hukum yang

${ }^{18}$ <http: www.Kompas.com>, diakses tanggal 25 Oktober 2011. 
lebih mencerminkan keinginan elit politik yang berada dalam sentrum kekuasaan eksekutif dan legislatif. ${ }^{19}$

\section{Penempatan KPK sebagai Organ UUD 1945}

Berdasarkan Undang-Undang Nomor 30 Tahun 2002 Tentang Komisi Pemberantasan Tindak Pidana Korupsi disebutkan bahwa salah satu gagasan awal pembentukan KPK tidak terlepas dari performance capaian lembaga penegak hukum yang ada. Terkait hal tersebut, konsideran Undang-Undang Nomor 30 Tahun 2002 menyatakan, lembaga pemerintah yang menangani perkara tindak pidana korupsi belum berfungsi efektif dan efisien dalam memberantas tindak pidana korupsi. Karena disfungsi itu, praktik korupsi menjadi tidak terkendali yang secara sistematis menghancurkan perekonomian nasional. Dampak korupsi tidak hanya terbatas pada kehidupan ekonomi, tetapi juga berujung pada pelanggaran terhadap hak-hak sosial dan hak-hak ekonomi masyarakat. ${ }^{20}$

Prestasi dan produktivitas KPK yang berhasil membongkar korupsi selama ini tidaklah berarti tanpa tantangan, namun justru telah menjadi preseden buruk bagi lingkaran politik dan birokrasi yang korupsi untuk lebih protektif dengan menggunakan segala cara untuk mereduksi ruang gerak KPK, yakni antara lain memangkas fungsi-fungsi dasar KPK (penyidikan, penyadapan, dan penangkapan). Upaya merevisi Undang-Undang KPK yang sedang dipersiapkan oleh DPR RI saat ini dinilai oleh kalangan tertentu menunjukan adanya keinginan elit politik tertentu untuk mengurangi kewenangan KPK. Pengurangan kewenangan institusi pemberantasan korupsi memang sering terjadi, bahkan dalam sejarah pemberantasan korupsi di Indoneisa sudah begitu banyak tim pemberantasan korupsi yang pernah dibentuk pemerintah tetapi ironisnya selalu berujung pada pelumpuhan kewenangan.

Berdasarkan catatan ICW sepanjang sejarah pemberantasan korupsi di Indonesia, cukup banyak peraturan perundang-undangan yang pernah dikeluarkan untuk memberantas korupsi dan sekitar 7 (tujuh) institusi pemberantasan korupsi patah tumbuh hilang berganti. Bahkan 4 (empat) diantaranya sengaja dimatikan setelah mencoba agak keras menyeret penguasa dengan delik korupsi. ${ }^{21}$ Pertama, Keputusan Presiden Nomor 228 Tahun 1970, kedua, Keputusan Presiden Nomor 12 Tahun 1970 tanggal 31 Januari 1970 dibentuk Tim Komisi Empat. Ketiga, pada tahun 1970 diusung nama baru yakni Komite Anti Korupsi, keempat, pada tahun 1977 dikeluarkan Instruksi Presiden Nomor 9 Tahun 1977 tentang Tim Operasi Ketertiban. Kelima, pada tahun 1982, Tim Pemberantasan Korupsi diaktifkan kembali meskipun Keputusan Presiden yang mengatur tugas dan kewenangan tim ini tidak pernah diterbitkan. Keenam, melalui Keputusan

19 Lihat Moh.Mahfud MD yang menguraikan karakter produk hukum dalam bukunya "Politik Hukum di Indonesia", (Jakarta: LP3ES, 1998).

\footnotetext{
${ }^{20}$ Saldi Isra, "Kekuasaan dan Perilaku Korupsi”, (Jakarta: Kompas, 2009), hal. 180.

${ }^{21}$ Harian Kompas, tanggal 7 Mei 2009.
} 
Presiden Nomor 127 Tahun 1999 dibentuk Komisi Pemeriksa Kekayaan Penyelenggara Negara. Ketujuh, berdasarkan Peraturan Pemerintah Nomor 19 Tahun 2000 dikukuhkan Tim Gabungan Pemberantasan Tindak Pidana Korupsi (TGPTK). Akan tetapi TGPTK mendapatkan "perlawanan" karena akhirnya diuji materikan ke Mahkamah Agung. Keputusan Mahkamah Agung adalah membatalkan Keputusan Presiden Nomor 19 Tahun 2000 sehingga TGPTK bubar.

Dalam rangka mencegah pelumpuhan kewenangan KPK maka salah satu strategi yang dapat dilakukan adalah menjadikan KPK sebagai guardian good governance yang mandiri dan independen. Untuk itu paramater utama yang berpengaruh besar dalam menentukan KPK sebagai lembaga negara yang mandiri dan independen yaitu reposisi kelembagaan KPK dalam peraturan perundangundangan. Dalam hal ini harus dilakukan penguatan KPK sehingga tidak hanya sebagai sebuah komisi negara yang bersifat ad hoc, dan dianggap sebagai lembaga negara inferior karena dibentuk oleh Undang-Undang, melainkan secara kelembagaan KPK harus dimasukan sebagai organ konstitusi yakni KPK diatur dalam pasal-pasal Undang-Undang Dasar Negara RI Tahun 1945.

Akan tetapi perlu dipahami bahwa penempatan KPK dalam UndangUndang Dasar Negara RI Tahun 1945 bukanlah sebagai bagian dari kekuasaan kehakiman. Dalam susunan kekuasaan negara Republik Indonesia, kekuasaan kehakiman diartikan sebagai kewenangan untuk menentukan hukumnya dalam suatu sengketa/perkara atau kewenangan untuk mengadili suatu sengketa/perkara. Dengan kata lain kekuasaan kehakiman adalah suatu kekuasaan yang berwenang menentukan bagaimana ketentuan hukumnya yang, harus diterapkan terhadap sengketa perkara yang dihadapkannya. Dalam hal ini salah satu fungsi kekuasaan kehakiman menurut CF Strong adalah untuk memutus perkara dengan menerapkan hukum (materiil) secara paksa (to decide upon the application of the existing law ... by its nature coersive). ${ }^{22}$

Adapun kekuasaan kehakiman di Indonesia diatur dalam Pasal 24, 24A, 24B, dan 24C Undang-Undang Dasar Negara RI Tahun 1945. Menurut Pasal 24 Ayat (2) Undang-Undang Dasar Negara RI Tahun 1945 disebutkan bahwa kekuasaan kehakiman dilaksanakan oleh Mahkamah Agung (MA), badan-badan peradilan lain dibawah Mahkamah Agung yang terdiri dari Peradilan Umum, Peradilan Tata Usaha Negara, Peradilan Militer, dan Peradilan Agama, serta sebuah Mahkamah Konstitusi.

Oleh karena itu untuk memasukan KPK sebagai bagian dari organ UndangUndang Dasar Negara RI Tahun 1945 maka KPK sebaiknya dimasukan sebagai bagian dari Bab XA yang memuat Pasal 28, 28A-28J tentang Hak Asasi Manusia. Hal ini artinya KPK disebutkan secara jelas dalam pasal pasal tersebut sebagai lembaga negara yang berwenang memberantas kejahatan korupsi sebagai pelanggaran hak asasi manusia. Pada dasarnya kejahatan korupsi dikategorikan sebagai extra ordinary crime yang bisa disetarakan dengan genocide, dan kejahatan kemanusian lainnya. Pencantuman KPK dalam pasal-pasal hak asasi manusia sebagai penjabaran dari ratifikasi pemerintah atas dokumen internasional 1952), hal. 8.

${ }^{22}$ CF. Strong, "Modern Political Constitution", (London: Sidgwick \&Jackson Limited, 
pemberantasan korupsi seperti salah satunya adalah United Nations Convention Against Coruption (UNCAC) 2003, dan kini telah diundangkan dalam UndangUndang RI Nomor 7 Tahun 2006 Tentang Pengesahan United Nations Convention against Corruption.

Penempatan KPK dalam pasal-pasal Undang-Undang Dasar Negara RI Tahun 1945 tidak terlepas dari kepercayaan publik (public trust) dan ekspektasi publik terhadap KPK yang masih cukup tinggi. Hal ini dapat diukur dari besarnya volume pengaduan masyarakat kepada KPK yang terus meningkat dari tahun ke tahun. Bahkan dalam tahun 2011 tercatat 51.000 (lima puluh satu ribu) lebih pengaduan yang sebagian besarnya bersumber dari masyarakat. ${ }^{23}$ Berdasarkan pengaduan yang cukup banyak itu sudah tentu diharapkan KPK ditempatkan sebagai organ Undang-Undang Dasar Negara RI Tahun 1945. Untuk menunjang hal tersebut perlu pengembangan kapasitas (capacity building) dalam tubuh KPK. $\mathrm{Hal}$ ini dilakukan antara lain dengan penambahan jumlah pegawai KPK karena saat ini anggota KPK hanyalah 500 orang dan penyidik 170-an orang, sedangkan wilayah negara RI luas dengan 498 kabupaten/kota dan 33 provinsi, dimana hampir semua daerah ada korupsi.

\section{Penutup}

Salah satu gagasan awal pembentukan KPK tidak terlepas dari performance capaian lembaga penegak hukum yang ada. Terkait hal tersebut, konsideran Undang-Undang Nomor 30 Tahun 2002 menyatakan, lembaga pemerintah yang menangani perkara tindak pidana korupsi belum berfungsi efektif dan efisien dalam memberantas tindak pidana korupsi. Karena disfungsi itu, praktik korupsi menjadi tidak terkendali yang secara sistematis menghancurkan perekonomian nasional. Dampak korupsi tidak hanya terbatas pada kehidupan ekonomi, tetapi juga berujung pada pelanggaran terhadap hak-hak sosial dan hak-hak ekonomi masyarakat.

Namun KPK dalam menjalankan tugas dan wewenangnya untuk memberantas korupsi ternyata tidaklah mudah. Dalam praktiknya, KPK tidak mampu menjangkau semua lembaga negara karena alasan normatif. Dalam hal ini keberadaan KPK yang secara kelembagaan lahir dari undang-undang, akan kesulitan melakukan akses pemberantasan korupsi terhadap lembaga-lembaga negara yang legitimasinya merupakan ketentuan langsung dari amanat UndangUndang Dasar Negara RI Tahun 1945.

Selain itu akibat kedudukan KPK yang hanya diatur dengan undang-undang maka KPK mengalami problematika, yakni Undang-Undang KPK secara formal (wet in formele zin) dibuat dan ditetapkan oleh DPR dan Presiden, maka undangundang KPK mudah dicabut oleh kedua lembaga negara yang membentuknya. Kemudian secara materil (wet in materiele zin), isi atau substansi dari undangundang KPK mudah direvisi oleh pemerintah dan DPR guna menyusupkan kepentingan politiknya masing-masing, sehingga undang-undangn KPK nantinya

${ }^{23}$ Warta Berita Pagi RRI Jakarta, 02 Juni 2011. 
lebih merupakan pencerminan visi elit politik. Produk hukum seperti ini dapat mengarah kepada produk hukum konservatif atau ortodoks yakni produk hukum yang lebih mencerminkan keinginan elit politik yang berada dalam sentrum kekuasaan eksekutif dan legislatif. Untuk mencegah pelumpuhan kewenangan KPK maka perlu penempatan KPK dalam Undang-Undang Dasar Negara RI Tahun 1945. 


\section{Daftar Pustaka}

\section{Buku}

Asshiddiqie, Jimly, Perkembangan dan Konsolidasi Lembaga Negara Pasca Reformasi, Jakarta: Sekretariat Jenderal dan Kepaniteraan Mahkamah Konstitusi RI, 2006. , Hubungan Antar Lembaga Negara Pasca Perubahan UUD 1945, Jakarta: Gramedia, 2008.

Strong, CF. Modern Political Constitution, London: Sidgwick \&Jackson Limited, 1952.

Adji, Indriyanto Seno. dalam Satya Arinanto, Memahami Hukum, Jakarta: Raja Grafindo Persada, 2009.

Astawa, I Gde Pantja. Dinamika Hukum dan Ilmu Perundang-Undangan di Indonesia, Bandung: Alumni, 2008.

Hamidi, Jazim, dkk, Teori dan Politik Hukum Tata Negara, Yogyakarta: Total Media, 2009.

Mahfud MD, Moh. Politik Hukum di Indonesia, Jakarta: LP3ES, 1998. , Expert Meeting tentang Permohonan Judicial Review UU-KPK, makalah expert meeting di Pusat Kajian Anti Korupsi (PUKAT) UGM, ICM Yogyakarta, dan Kemitraan Jakarta, tanggal 12 13 Oktober 2006.

, Perdebatan HTN Pasca Amandemen Konstitusi, Jakarta: Raja Grafindo, 2010.

Isra, Saldi. Kekuasaan dan Perilaku Korupsi, Jakarta: Kompas, 2009.

\section{Jurnal Hukum}

Sekarmaji, Aji "Pemberantasan Kejahatan Korupsi Dalam Rangka Proses Penyesuaian Dengan Konvensi PBB Anti Korupsi”, dalam Jurnal Hukum dan Pembangunan, Tahun ke-39 No.2, April 2009.

Arief, Barda Nawawi "Beberapa Masalah dan Upaya Peningkatan Kualitas Penegakan Hukum Pidana Dalam Pemberantasan Korupsi”, dalam Jurnal Keadilan, Vol.5 No.1 Tahun 2011.

\section{Peraturan Perundang-Undangan}

Undang-Undang Dasar Negara Republik Indonesia Tahun 1945.

Undang-Undang Nomor 4 Tahun 2004 Tentang Kekuasaan Kehakiman. 
Undang-Undang Nomor 10 Tahun 2004 Tentang Pembentukan Peraturan Perundang-Undangan jo Undang-Undang Nomor 12 Tahun 2011 Tentang Pembentukan Peraturan Perundang-Undangan.

Undang-Undang Nomor 30 Tahun 2002 Tentang Komisi Pemberantasan Tindak Pidana Korupsi.

\section{Internet/Artikel Koran}

<http://www.kpk.go.id>, diakses tanggal 2 Mei 2011.

$<$ http://www.Kompas.com>, diakses tanggal 25 Oktober 2011.

Diansyah, Febri. Jangan Bunuh KPK, Jakarta: Kompas, 2009. 